\title{
Basophilic Normoblast Count
}

National Cancer Institute

\section{Source}

National Cancer Institute. Basophilic Normoblast Count. NCI Thesaurus. Code C147405.

The determination of the amount of basophilic normoblasts present in a sample from an experimental organism. 